\title{
Reinventing Traditional Malay House for Sustainable Housing Design: Obstacle and Proposed Solution
}

\author{
Ibrahim S.H $\mathrm{H}^{\mathrm{a}^{*}}$, Liew A.A.H ${ }^{\mathrm{a}}$., Nawi M.N.M ${ }^{\mathrm{b}}$,,Yusoff M.N $\mathrm{N}^{\mathrm{c}}$ \\ ${ }^{a}$ Department of Civil Engineering, Faculty of Engineering, Universiti Malaysia Sarawak (UNIMAS),,Kota Samarahan, Sarawak, Malaysia \\ ${ }^{b}$ School of Technology Management and Logistic, Universiti Utara Malaysia, 06010 Sintok, Kedah, Malaysia \\ ${ }^{c}$ College of Law, Government and International, Universiti Utara Malaysia, 06010 Sintok, Kedah, Malaysia
}

*Corresponding author: ihalipah@feng.unimas.my

Article history

Received: 19 June 2014

Received in revised form:

25 September 2014

Accepted: 1 December 2014

Graphical abstract

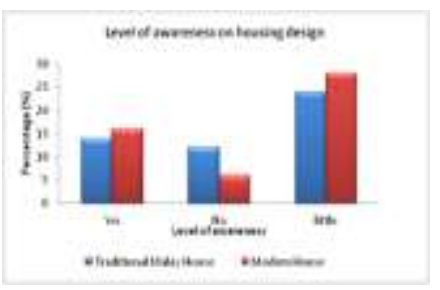

\section{Abstract}

Traditional Malay House design has the key of energy efficiency dwelling to create a sustainable housing. Today, modern houses are massively built replacing the Malaysia's heritage house. Despite of this rapid development, the owners are aware on the drawback of this type of houses. Therefore, this study is conducted to investigate factors of developers reluctant to build the Traditional Malay House and correct the public misconception toward the housing perception. Survey questionnaire and in-depth interview were conducted. The results indicate that costing is the major problem for housing developers to construct Traditional Malay House.

Keywords: Traditional malay house, sustainable home, modern house, malay house evolution C 2014 Penerbit UTM Press. All rights reserved.

\subsection{INTRODUCTION}

World has experienced devastating natural disasters that caused by global warming. It is impossible to instantly stop global warming, but efforts could be done to reduce the effect of this scenario. Wanek [1] stated that the building is the largest energy consumption. Therefore, the solution to global warming must involve the sustainable design of the building.

Considering current economic unstable condition, retrofitting an existing building could be more cost effective than rebuilding a new facility in order to create a sustainable home. As one of the cultural heritage in Malaysia, the Traditional Malay House should be kept as a reference for the next generation. However, the design seems to be faded with time and replace by massive construction of modern house such as semi-detached house and terrace house.

Traditional Malay House is an excellent model for today's architects and designers in understanding climatic and environmental design, building systems, and design flexibility [2]. Rahman [3] stated that it is ironic that the traditional Malay house, can achieve a degree of passive control to achieve comfort condition. Therefore, reinvent the Traditional Malay House could be the ultimate solution in producing more sustainable home.
However, the indigenous house seems to ignore by today society including the most of the Malay people. They haste for Westerntype progress and modernity, many of its virtues have been abandoned [4]. Therefore, this study had been conducted to explore the advantages of Traditional Malay House that can be preserved and overcome the drawback in creating more sustainable house. Apart from that, comparison will be made to the modern house particularly detached house in Malaysia. This research also dissect the factors contribute to the rapid development of modern houses and also, reveal cause of the ignorance in Traditional Malay House design.

\subsection{LITERATURE REVIEW}

Malay House is one of the best examples of sustainable design. Many researchers believed that Traditional Malay House is carefully designed in accordance to the weather, and thus, resulting in a climatically responsive house that provides comfort for the dwellers $[2,3,5]$. This summarize that Traditional Malay House has high energy efficiency. In contrast, modern house design especially terrace houses are based on cold climate region 
where houses cuddled together help keep the population warm during the long cold winter.

Most modern housing developments in Malaysia built under the new standards and regulations have been planned on a gridiron layout to maximise the use of the land and hence building densities. To maximise the use of land evermore, most of the houses are built in terrace form. This sort of housing development pays little respect to the local landscape and thus causes a negative impact on the environment. Unfortunately, terraced housing represents the most common type now being built in urban areas.

The terraced house is a relatively new concept to Malaysia and was introduced in the early 1980's in response to the need to economise on the land used. The houses which are being built take little account of the internal layout and other comfort requirements of the potential buyers.

It has already been stated that terraced housing destroys the aesthetics of the local environment, and that such layout are not based on environmental concerns. The concept is based on massproduction has a negative influence the house design and the surrounding landscape. All it does is to increase the speed of construction at the cost of everything else. Scoffham [6] argued that the system has a standard design which is aimed to promote uniformity in housing development.

Usually modern houses need mechanical means to control their indoor temperature. Besides that, a number of researchers reported that modern house use high thermal capacity materials such as bricks, tiles and concrete that store up heat and reradiate it into the house, causing considerable discomfort [5,7]. Despite the problems cause by the modern house, these houses are growing massively. Therefore, other alternative should be considered such as reinventing Traditional Malay House. It might not practical to build the actual feature of Traditional Malay House in urban areas, but lessons can be drawn from the climatic design of the Traditional Malay House for housing in the modern context. Traditional Malay House could easily found in West Malaysia but in Sarawak also has their own unique design features that influenced by colonial design.

Rapid development of housing in worldwide has leave great impact on the environment. It is impossible to stop the development as the demand of housing keep increasing each year. However, effort can be done in avoiding any further deterioration in the environment. Therefore, one of the efforts is by design sustainable building and in this study focusing on residential building.

\subsection{METHODOLOGY}

This study adopted a quantitative methodology to explore and assess the perspectives of the occupants of these two (2) type of houses and those who involve in the construction industry to get a better understanding of public knowledge, experience and responses towards Traditional Malay House and Modern house.

The questionnaires are distributed through (i) e-mail questionnaire and (ii) interviewer-administered questionnaire. The questionnaire comprised of three (3) sections containing a total of fifteen (15) questions designed to investigate the validity of industry evidence on housing design. The questionnaire comprised rating, multiple choices, and closed-ended questions, consist of combination of factual, opinion and knowledge questions in relation to the salient issues of the research. Additional space was included at the end of the questionnaires for respondents to elaborate on their responses. The target samples are dividing into two groups. The target for first group is Kuching citizen who lives in Traditional Malay House while second group is Kuching citizen who lives in a modern detached house.

As for the in-depth interview, the questions has been prepared with guidelines to get a better understanding on the acceptance or ignorance from developers, construction firm, and architecture firm regarding on the unique house and its features. The targets are groups of people involve in professional field including developers, engineering or consultant company and architecture firm. All of them are selected from Kuching only.

\subsection{DESCRIPTION OF TRADITIONAL MALAY HOUSE AND MODERN HOUSING IN KUCHING, SARAWAK}

\subsection{Common Features of Traditional Malay House}

Basically, Traditional Malay House is a timber house raised on stilts. In Kuching, most of the material used for constructing these houses is hard wood such as 'Belian' and 'Selangan Batu'. Many of the houses uses 'belian' shingles as part of the roofing system, but nowadays had been replaced with metal roof which is claimed to be more durable. The roofs are very steep with elongated overhangs for shading and protection from heavy rain. The facades are recessed and almost hidden behind the long roof overhangs. It has large openings that allow maximum ventilation. The floor is raised on stilt making no contact with the ground, again allowing natural ventilation and avoiding conduction of heat from the ground. The indoor is as open plan as possible, with loosely arrange furniture creating transparency of light and ease the natural ventilation. The Malay Traditional Architecture is a reflection of careful understanding of our people towards their environment. In many cases, they have beautifully carved timber eaves to decorate the 'visual connection' between roof and sky. Their windows are plentiful, lining the walls and providing good ventilation and views for the house. Although they use timber as main structure, amazingly they are built without a single nail, instead the Malays used pre-cut holes and grooves to fit the timber building elements into one another, effectively making it a 'pre-fabricated house'. There are handcrafted panels, holed carvings and slatted panels around the walls.

In Sarawak, a typical home design of Traditional Malay House as shown in Figure 1, located in Malay villages basically have common with the most Traditional Malay House in Peninsular Malaysia.

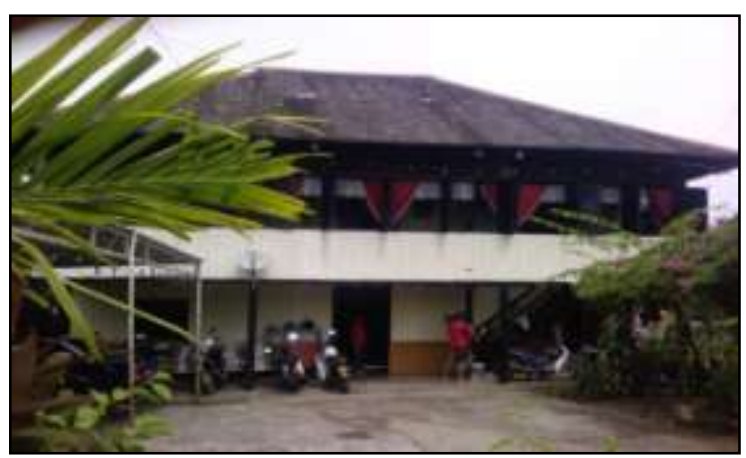

Figure 1 Traditional Malay House in Kuching, Sarawak

An urban Malay house is a gracious structure well-adapted to the climate. The front room takes up the width of the house and is an area designated for men, official occasions and entertaining 
guests. The building has windows cut down to the floor level to allow breeze circulation and artistic skills are lavished on the decoration of the stair and window railings, fascia boards under the eaves, ventilation grills above or beside the doorways. There is an attic above the bedroom area connected by a wooden staircase. It is used commonly for storage space only and not for communal living mainly due to the relatively hotter air closes to the rooftop. Another common but unique feature of a Malay house is the grille on the side windows to allow better air circulation.

Traditional Malay House usually use lightweight construction of wood and other natural materials of low thermal capacity holds little heat and cools adequately at night. According to Killman et. al [8], the roof made of palm leaves were most widely used. The Malays term for palm-thatched roofs, attap, is also used as a synonym for roof in general. Leaves of sago palm (Metroxylon sagu or Metroxylon rumphiirumbia) were preferred, because they last two to three years longer than those of the nipah palm. Organic materials, especially attap, provide an ideal climate inside the buildings. They cool the room during the day and warm them at night. The structured surface absorbs the impact of raindrops during downpours and reduces their noise.

But after industrial revolution, the mindsets of people have changed drastically. They crave for more of fancy designs that involve the use of materials that are not available locally but are imported from different cities of the country or altogether different nations of the world. This style is called Modern Housing.

\subsection{Common Features of Modern Housing}

In modern housing design is characterized by a window wall, a large and sophisticated curtain, with less decoration on the walls of houses and housing compared to the past. Modern housing in Malaysia at present equipped with basic facilities that can meet the needs and comfort to the residents [9].

In Malaysia, vague building standards exist but they are mainly concerned with housing costs and density and do not specify guidelines for any aspect of human comfort. Tahir [10] investigated the environmental quality of modern low-income housing and concluded that one of the main drawbacks in most of the housing is the poor internal layout. This often fails to relate to the basic social and cultural structure of Malaysian people. A few previous research on user response in low cost housing showed that a large percentage of the occupants are dissatisfied and disappointed with the housing provision. Rajeh [11] had shown that terraced houses are often poorly ventilated. The cause is reported to be simply due to insufficient openings in the building to allow for cross-ventilation. A Study by Ibrahim et. al [6] pointed out that the size and design of many low-income houses is inadequate and therefore extension of the house is unavoidable. The study also reported that a majority of the occupants were unsatisfied with the thermal comfort level provided inside the house caused by higher temperatures. The study further emphasized the well known fact that lack of air ventilation and air movement inside the houses caused people to sweat and feel uncomfortably hot for about four to six hours a day. In most lowincome house design, ventilation is expected to be provided by means of open doors and windows [12].

Modern houses generally match the current technology trends and usually attract young adults. Architects are constantly changing plans to reinterpret what the idea of modern house and end-up with simple and rigid design that not suitable for local climate.
In this project, detached houses are chosen for data sampling as shown in Figure 2 and 3 which is similar to Traditional Malay House.

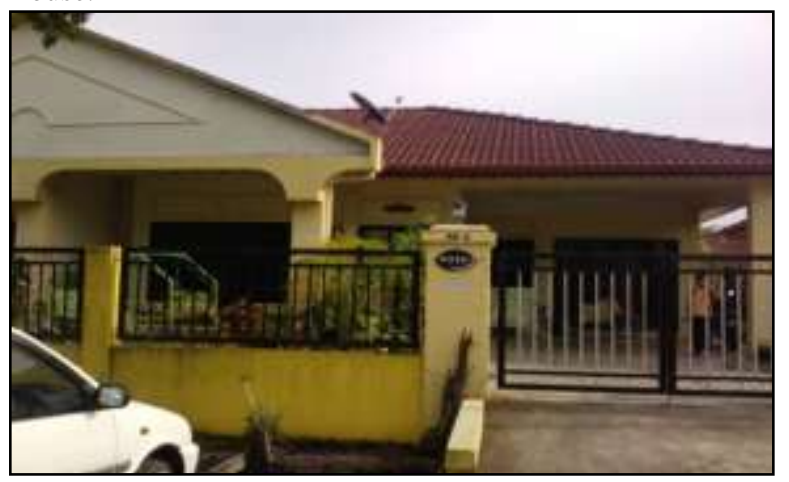

Figure 2 Modern House in Kampung Gita Baru

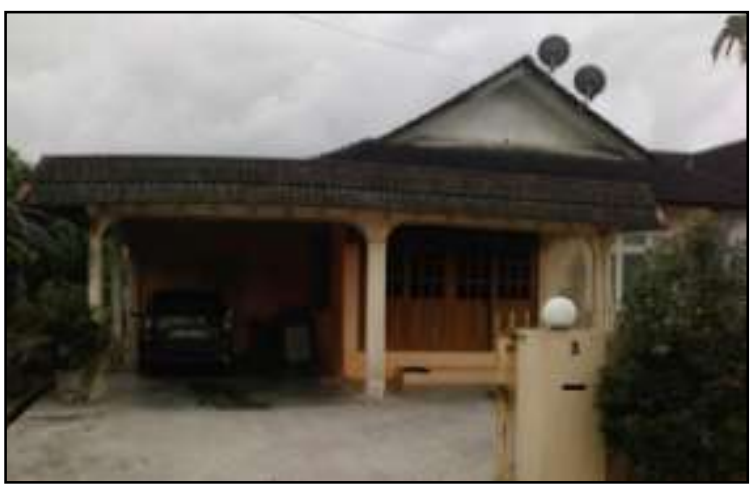

Figure 3 Modern House in Taman Lee Ling

Their main construction material would be concrete and composite building materials (Nawi et. al [13]). Those houses do not have specific features like Traditional Malay House. All spaces have a live function with flexible floor plan. Most of the houses have porch area in front of the house with function not only for carpark but also as informal communal area.

\subsection{Comparison Between Traditional Malay House And Modern House In Malaysia}

After reviewing the features in both Traditional Malay House and modern house, we can see that modern housing estate houses are not designed based on local climate and ignore the basic requirements for thermal comfort. Nevertheless, it is not practical to build the entire features of Traditional Malay House in the urban areas, but lessons can be drawn from the climatic design of the Traditional Malay House for housing in the modern context.

The use of building materials such as wood and thatch for house building might not be able to suite the high density living in urban areas, but other features of the Traditional Malay House can be adapted to improve today's modern house condition. The best example can be taken from the semi-colonial house which adapts the Traditional Malay House feature into their origin (British) house design.

\subsection{RESULT AND DISCUSSION}

A total of 50 set questionnaires are successfully distributed to respondents; 25 sets to respondents who lives in Traditional Malay 
House and another 25 set of questionnaires are distribute to those who lives in modern house. The survey conducted restricted to Kuching district only. Selected houses are located at Kampung No.2 , Kampung No.3, Kampung Lintang, Kampung Sungai Bedil, Kampung Panglima Seman and Kampung Boyan as shown in Figure 4.

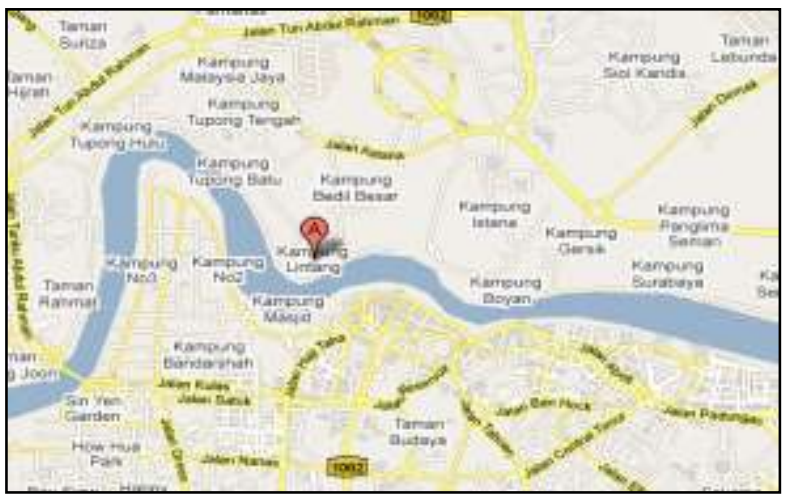

Figure 4 Maps of Kampung No.2 , Kampung No.3, Kampung Lintang, Kampung Sungai Bedil, Kampung Panglima Seman and Kampung Boyan. (Source: google map)

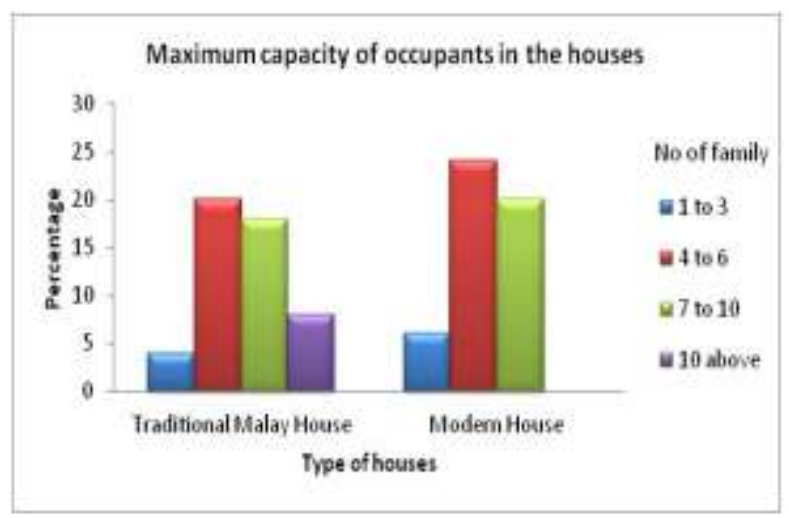

Figure 5 Result of maximum capacity by both Traditional Malay House and Modern House

Figure 5 shows that traditional Malay houses could manage to accommodate more than 10 people at one time compare to modern houses with the maximum capacity 10 people. This scenario agreed with Malay cultures that indicate that Malay people prefer to live with extended family. Due to extended family factors in Malay culture, most of the children continue to live with their parents until they are capable to support themselves by renting a room or building their own houses. Sometimes they stay with their parents up to their late twenties or beyond, even after marriage. Thus, parents feel obliged to transform their houses to provide more and better spaces to accommodate their growing families. Sometimes the house could accommodate up to three generations, living together in the same house. After certain period of times, and the number of family increased, this will be reflected in the extended of space of the house.

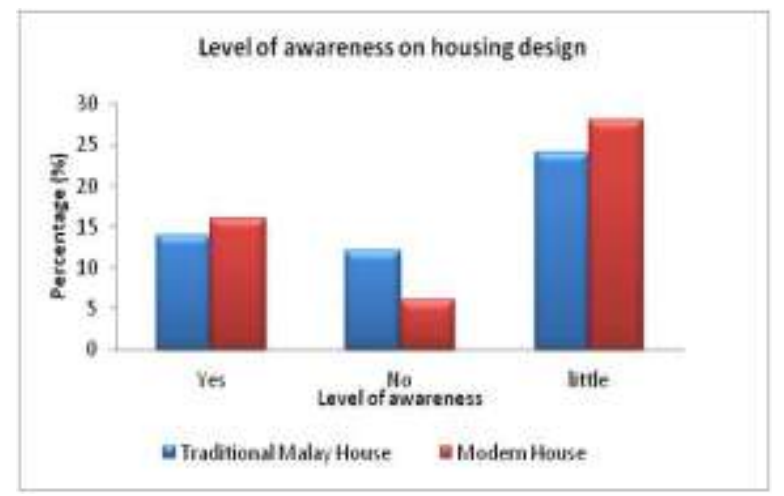

Figure 6 Rate of public awareness on modern house and Traditional Malay House design

Figure 6 shows the level of awareness on modern house and Traditional Malay House design. About 33.3\% respondents stated that they are aware of the design either modern house or Traditional Malay House design. This means $70 \%$ of people do not have any idea or only basic knowledge of housing design. The home buyers rely on the engineers and architect and developer to design and construct type of houses available in the market.

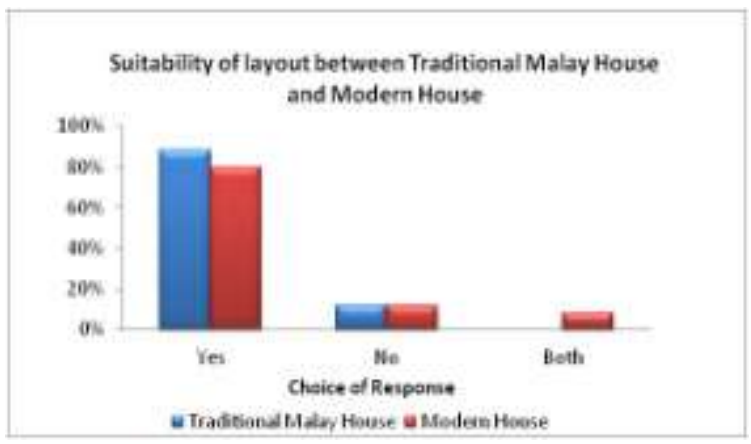

Figure 7 The Comparison of layout comfort between Traditional Malay House and Modern House

Figure 7 is the result of modern house and Traditional Malay House on their suitability in term of the layout. $88 \%$ of Traditional Malay House residents are comfortable with the layout or arrangement of spaces in their house; on the other hand, $80 \%$ of modern house residents feel comfortable with the layout of their house as well. In addition, there are $20 \%$ of modern house residents choose 'No' and 'Both' answer to indicate that the design can have better improvements. According to Rahman [3], the layout of Traditional Malay House it has basically the front and back portions which are centred around Rumah Ibu (core house) with Dapur (kitchen). From the entrance, stairs lead up to a covered porch or verandah called Anjung. The porch acts as a good transition space between the public and the private domains.

In Kuching, most of the modern houses use the similar concept. They usually prefer living rooms that have access to other rooms such as bedroom, toilets and kitchen. Hence, it is not a surprise when find out that the percentage of both data are almost the same. 
Table 1 Result of frequency of using thermal control devices and natural air ventilation

\begin{tabular}{|c|c|c|}
\hline $\begin{array}{c}\text { Thermal control } \\
\text { devices }\end{array}$ & $\begin{array}{c}\text { Traditional Malay } \\
\text { House }\end{array}$ & Modern House \\
\hline fan & 23 & 23 \\
\hline air-conditioning & 6 & 12 \\
\hline door/window & 23 & 15 \\
\hline
\end{tabular}

Table 1 indicates the people who live in modern houses rely more on air-conditioning in compare to those who live in Traditional Malay House the former has a focus on natural air ventilation (passive design) to provide comfort towards their environment.

Today, the reliance on natural air ventilation is gains less attention by the architects who prefer to use mechanical cooling system as main factors to provide thermal comfort [14]. According to Omer [15], almost $68 \%$ of the energy is used for Heating, Ventilating and Air Conditioning Systems (HVACs). If this issue is taken lightly, most probably we would face inefficient use of energy in the future. Another finding through the survey is, 94\% from all of the respondents prefer and comfortable using natural ventilation than using thermal control devices such as fan and air-conditioning system.

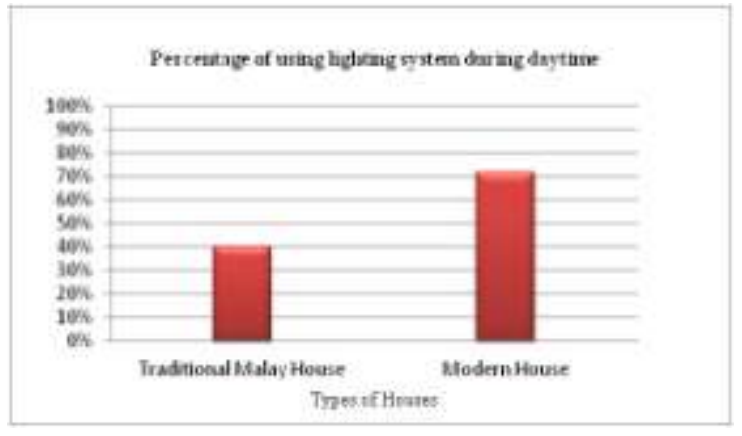

Figure 8 Percentage using lighting system during daytime

Analysis on Figure 8 indicates that the consumption of modern house for turning on lighting system $(72 \%)$ during the day is higher than that of Traditional Malay House (40\%). This means the energy consumption is higher for modern houses comparing to Traditional Malay House.

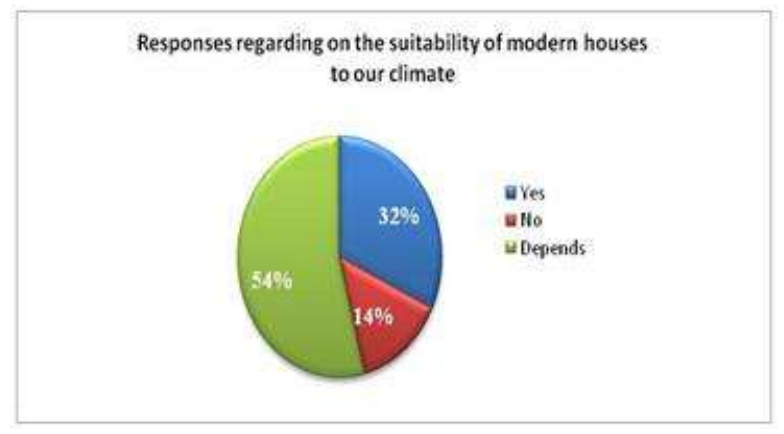

Figure 9 Responses regarding on the suitability of modern houses to our climate

Massive construction of modern houses nowadays does not proved the houses are the most comfortable house to live in. Figure 9 shows $54 \%$ of the response claim that modern house today is not entirely suitable to our climate. Another $32 \%$ disagree that the modern houses is not suitable with our environment. Therefore, the existing number of modern houses could not indicate the level of acceptance of people towards this type of houses.

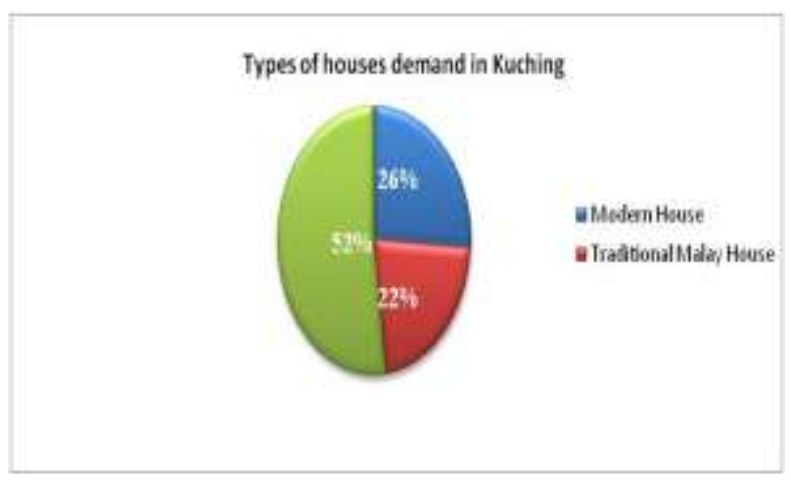

Figure 10 Types of houses demand in Kuching

Obviously, most of the respondents either lives in Traditional Malay House or modern house are fond of the idea of reinventing Traditional Malay House. This result proven that the peoples in Kuching do not exactly all satisfy with the modern house design today. There is certainly having serious buyers for the proposed reinventing Traditional Malay House design.

\subsection{In-Depth Interview Analysis}

For this project, it is important to identify the source of problem in implementing Traditional Malay House features into modern houses design. Survey analysis from both client (the public or residents) and the developers, engineers and architects, are essential to achieve the project objectives. In-depth interviews were conducted with the architectural companies and developers and other professionals in construction field. These groups are chosen in order to provide a suitable sampling frame due to their pivotal role though leadership and significant involvement in the initial briefing, conceptual and design development phases of a project.

The feedback and outcomes from the interview session with the respondents could be classified as:

a. Factors contribute to rapid development of modern houses

b. Obstacle faced by developers, engineers and architects to construct Traditional Malay House in Kuching

c. Positive response from Developers, Engineers and Architects in Kuching

\begin{tabular}{|c|l|}
\hline \multicolumn{2}{|c|}{ (a) Factors contribute to rapid development of modern houses } \\
\hline Cost & $\begin{array}{l}\text { For developers and engineers, the main consideration } \\
\text { of constructing a project is the cost factor. They try any } \\
\text { possible way to optimise the budget. If possible, they } \\
\text { would try to avoid project delay due to costing factors. } \\
\text { Most of the developers and contractors are interested in } \\
\text { constructing modern houses because they are familiar } \\
\text { with the methods of construction and could be repeated } \\
\text { easily. }\end{array}$ \\
\hline Material & $\begin{array}{l}\text { A number of concrete and steel supplier and } \\
\text { manufacturer located in Kuching and this situation } \\
\text { would lead to easy accessibility for developers and } \\
\text { contractors towards those materials. }\end{array}$ \\
\hline
\end{tabular}




\begin{tabular}{|c|c|}
\hline $\begin{array}{c}\text { Design } \\
\text { approval }\end{array}$ & $\begin{array}{l}\text { The developers of modern housing design need to get } \\
\text { approval under the Building Ordinance } 1994 \text { from the } \\
\text { authorities such as Kuching North City Hall and South } \\
\text { Kuching Municipal Council. } \\
\text { Every project need to satisfy the requirement of } \\
\text { authorities based on the guidelines stated in the } \\
\text { Building Ordinance } 1994 \text {. Most of the modern housing } \\
\text { design in Kuching is not significantly different. } \\
\text { Therefore, the process for plan approval would not face } \\
\text { many problems and thus can be execute easily. }\end{array}$ \\
\hline Labor & $\begin{array}{l}\text { Most of modern housing construction need unskilled } \\
\text { workers and semi-skilled workers. Only several skill } \\
\text { workers are needed such as site supervisor and } \\
\text { engineers to complete the projects. }\end{array}$ \\
\hline Trend & $\begin{array}{l}\text { Projects are usually built according to market demand. } \\
\text { When more houses sold out means they are making } \\
\text { more profit. According to the professionals, modern } \\
\text { house design is the most popular trend. This means } \\
\text { higher market demand for modern house. }\end{array}$ \\
\hline \multicolumn{2}{|c|}{$\begin{array}{l}\text { (b) Obstacle faced by developers, engineers and architects to } \\
\text { construct Traditional Malay House in Kuching }\end{array}$} \\
\hline Material & $\begin{array}{l}\text { First thing that comes into the developers and } \\
\text { professionals (engineer and architect) mind is timber. It } \\
\text { is consider expensive material in Malaysia. In order to } \\
\text { construct a high quality wooden house, hardwood is } \\
\text { usually used such as Belian and Selangan Batu. } \\
\text { Another problem is there are not much manufacturer } \\
\text { and supplier in Kuching. Although Sarawak has the } \\
\text { largest amount of rainforest than any state in Malaysia, } \\
\text { but most of the hardwood are exports elsewhere. }\end{array}$ \\
\hline Cost & $\begin{array}{l}\text { Besides the material, there are few other factors that } \\
\text { would influence the cost such as method of } \\
\text { construction and high maintenance cause by the termite } \\
\text { problems. When the workers are not familiar with } \\
\text { method of construction, there probably would be new } \\
\text { problem arise and lead to delay. Again, delay will } \\
\text { increase the cost of the project. }\end{array}$ \\
\hline $\begin{array}{l}\text { Lack of } \\
\text { knowledge } \\
\text { and } \\
\text { experience }\end{array}$ & $\begin{array}{l}\text { Most of the engineer and architect are lacking of } \\
\text { exposure and knowledge } \mathrm{n} \text { the Traditional Malay } \\
\text { House. They claimed that they have insufficient info on } \\
\text { hardwood data in Sarawak, particularly Kuching. }\end{array}$ \\
\hline Maintenance & $\begin{array}{l}\text { Maintenance for Traditional Malay House is relatively } \\
\text { higher than modern house if the wood used is low } \\
\text { quality. It only has } 5 \text { year termite warranty. The } \\
\text { durability can decrease when exposed to sunlight and } \\
\text { rain. }\end{array}$ \\
\hline \multicolumn{2}{|c|}{$\begin{array}{c}\text { (c) Positive response from Developers, Engineers and Architects in } \\
\text { Kuching }\end{array}$} \\
\hline $\begin{array}{l}\text { Realize the } \\
\text { drawback of } \\
\text { modern } \\
\text { houses }\end{array}$ & $\begin{array}{l}\text { Despite massively constructing modern houses, the } \\
\text { developers, engineers and architects are actually aware } \\
\text { the drawback of its design. They agree that many of the } \\
\text { modern houses are using active design. In order to give } \\
\text { cooling effect to the house, they need to apply } \\
\text { mechanical devices such as air-conditioning and fan. } \\
\text { Very few are using passive design to maximize the } \\
\text { thermal comfort in the house. }\end{array}$ \\
\hline $\begin{array}{l}\text { Carving } \\
\text { elements } \\
\text { replaced by } \\
\text { aluminum }\end{array}$ & $\begin{array}{l}\text { Generally, aluminum cannot bring the same effect as } \\
\text { wood in term of thermal conductivity and insulation. } \\
\text { However, the combination of aluminium and wood can } \\
\text { give better result. In order to overcome cost of timber, }\end{array}$ \\
\hline
\end{tabular}

\begin{tabular}{|l|l|}
\hline & $\begin{array}{l}\text { the combination aluminium and wood frame provide } \\
\text { more reasonable price. }\end{array}$ \\
\hline $\begin{array}{l}\text { Positive to } \\
\text { develop } \\
\text { idea }\end{array}$ & $\begin{array}{l}\text { Overall, the developers and other related professionals } \\
\text { seems to agree and supportive in developing the idea of } \\
\text { Malay House Evolution. It can be done as long as the } \\
\text { obstacles discuss earlier could be settled. }\end{array}$ \\
\hline
\end{tabular}

\subsection{CONCLUSION}

In this study, it is clear that low public awareness in housing design have indirectly give chance to the developers or contractor to exploit the development of housing scheme. However, they are starting to realize the drawback of the modern house design. Most of them are more likely to accept the idea of reinventing Traditional Malay House and the need to propose a modern house that has been adapt traditional design to meet the residents desired by using new methods and construction materials. Therefore the reinventing process of the housing design is possible as long as people in this industry could work together to achieve the goal. This is crucial to ensure that modern houses design for Malaysian are in a good quality and fulfill the expectation of the people towards sustainable housing.

References

[1] Wanek, K. 2010. The Hybrid House: Designing With Sun, Wind,Water, And Earth. Utah: Gibbs-Smith.

[2] Lim, J. 2010. Malay House: Principles to Building Simple and Beautiful Homes for Comfort and Community. Fox Chapel Publishing

[3] Rahman, A.M. 1995. Housing Design In Relation To Environmental Comfort. Building Research \& Information. 23 (1): 49 - 54

[4] Tahir, M.M., Usman, I., Ani, A. C., Surat, M., Abdullah, N., \& Nor, M. M. 2009. Reinventing the Traditional Malay Architecture: Creating a Socially Sustainable and Responsive Community in Malaysia through the Introduction of the Raised Floor Innovation (Part1). Energy, Environment, Ecosystems, Development and Landscape Architecture Journal.

[5] Ibrahim, S.H. \& Tinker, J.A. 2005. Improvements to Thermal Comfort In Affordable Housing In Malaysia. Proceeding of International Conference on Sustainable Building South East Asia, Kuala Lumpur, Malaysia

[6] Scoffham, E.R. 1984. The Shape Of British Housing. George Godwin Ltd, London.

[7] Ibrahim, S.H., Baharun, A., Nawi, M.M., \& Junaidi, E. 2014. Analytical Studies on Levels of Thermal Comfort in Typical Low-Income Houses Design.UNIMAS e-Journal of Civil Engineering. 5(1)

[8] Killman, W., Sickinger, T., \& Hong, L.T. 1994. Restoring \& Reconstructing The Malay Timber House. Kuala Lumpur: Fores Research Institute Malaysia.

[9] Norazmawati Md. Sani, N. 2012. Modern houses design for Malaysian. Advances in Applied Science Research. 3(6) :3810-3813

[10] Tahir, T. 1985. Thermal Comfort In Low Cost Housing in Low Density Areas, B.A. Thesis, University Science of Malaysia, Penang, Malaysia

[11] Rajeh, S. 1994. Wind Ventilation Of Terrace in Malaysia. ISI-UTM International Convention and Exposition, January 24-26, Kuala Lumpur

[12] Wahid, J. 2000. The Role Of Culture In The Built Environment Of The Malays. Symposium of Malay and Melanau Culture. 12-13 March, 2000 Bintulu, Sarawak, Malaysia

[13] Nawi, M.N.M., Radzuan, K., Salleh, N.A. \& Ibrahim, S.H. (2014) Value Management: A Strategic Approach for Reducing Faulty Design and Maintainability Issue in IBS Building, Advances in Environmental Biology, 8(5) 1859-1863

[14] Hassan, A.S., \& Ramli, M. 2010. Natural Ventilation of Indoor Air Temperature: A Case Study of the Traditional Malay House in Penang. American J. of Engineering and Applied Sciences 3 (3): 521-528

[15] Omer, A.M. 2008. Renewable building energy systems and passive human comfort solutions. Renewable \& Sustainable Energy Reviews. 12(6):1562-1587 